\title{
(2) OPEN ACCESS \\ Newborn care technology investments for LMIC settings: a CPAP approach
}

\author{
Bolanle Aishat Kasali (D) , ${ }^{1}$ Anisha Gururaj, ${ }^{2}$ Maneesh Batra ${ }^{3,4}$
}

\begin{abstract}
1 Maternal, Newborn and Child Health Discovery and Tools, Global Health Division, Bill and Melinda Gates Foundation, Seattle, Washington, USA

2Maternal, Newborn and Child Health Discovery and Tools, Bill and Melinda Gates Foundation, Seattle, Washington, USA ${ }^{3}$ Division of Neonatology, Seattle Children's Hospital, Seattle, Washington, USA ${ }^{4}$ Department of Pediatrics, Division of Neonatology, University of Washington School of Medicine, Seattle, Washington, USA
\end{abstract}

\section{Correspondence to}

Dr Bolanle Aishat Kasali,

Maternal, Newborn and Child Health Discovery \& Tools, Global Health Division, Bill and Melinda Gates Foundation, Seattle, WA 98119, USA; Aisha.kasali@ gatesfoundation.org

Accepted 18 February 2021 Published Online First 7 April 2021

\section{Check for updates}

(c) Author(s) (or their employer(s)) 2021. Re-use permitted under $\mathrm{CC} B \mathrm{BY}$. Published by BMJ.

To cite: Kasali BA, Gururaj A, Batra M. BMJ Innov 2021;7:519-522.
Globally, it is estimated that 15 million babies are born prematurely each year. Approximately one million of these newborns die due to complications of preterm birth, and these deaths occur disproportionately in low/middle-income countries (LMICs). ${ }^{1}$ Respiratory distress syndrome (RDS) is a common cause of death among those born preterm, and continuous positive airway pressure (CPAP) has been established as an effective therapy for reducing mortality and morbidity from RDS among preterm neonates. ${ }^{2}$ Unfortunately, the high cost of conventional CPAP devices has limited its availability in low-resource settings. ${ }^{3}$ To fill this gap, multiple low-cost, effective and safe CPAP devices have emerged, although this space remains an area for active innovation and development. In this paper, we focus on the use of the target product profile (TPP) as a tool for aligning innovators and other stakeholders for product innovation. As a funding organisation, we are invested in the implementation of technology products that improve health outcomes at scale. We have observed the presence of multiple CPAP products without clear alignment on the key features and specifications, nor the systemic and delivery factors required for successful implementation. ${ }^{4}$ This has resulted in a major barrier to large scale uptake and implementation of CPAP devices for the treatment of RDS in preterm infants in LMICs.

Newborn technology design for respiratory distress can be done in a purposeful way. While clinical guidelines and recommendations on the clinical use of CPAP for newborn care are available, there is insufficient guidance to align innovators, investors and other stakeholders developing new product prototypes. The WHO (2015) issued a recommendation on the use of CPAP for the treatment of preterm newborns with RDS immediately on diagnosis. It includes provision of blended oxygen, monitoring of oxygen saturation and cardiorespiratory status, and use in facilities that can provide quality care to support newborns, ${ }^{5}$ as well as guidance on the core components of a home-made, or improvised bubble CPAP device. ${ }^{6}$ The recently released WHO standards for improving care for small and sick newborns also established CPAP as a treatment for newborns diagnosed with respiratory distress. ${ }^{7}$ In addition to this, we believe further guidance should be provided to innovators to guide technical design specifications and key considerations requisite for CPAP implementation in low-resource settings. This is critical to identifying where further innovation is needed, as well as to align the community on effective use of CPAP across geographies and health systems to ensure sustainable impact. The TPP may be a useful tool to create this alignment and guide stakeholders who are keen to innovate in this space.

In the last decade, the global health development sector has increasingly adopted the use of TPPs in product development for public health priority diseases in low-resource settings. ${ }^{8}$ The TPP is a strategic planning tool that defines the minimum and optimistic criteria or characteristics for a product to meet the needs of its target users or population. ${ }^{8}$ Establishing a TPP is useful for setting priorities to inform technology conceptualisation for public good. ${ }^{9}$ Furthermore, it articulates the intent and critical attributes of a product to guide research and development goals., It is vital for innovators to consider developing their own TPP or using publicly available TPPs when developing their product as a benchmark for consideration of all relevant product attributes. For example, UNICEF in collaboration with NEST 360 have developed 
TPPs for 16 different key newborn product categories, including CPAP. ${ }^{10}$

For funders, investors and programme implementers to better understand and segment the commercial landscape a TPP can help to identify where there may be gaps and barriers in the products needed to drive scale and global impact. For example, with CPAP, using a TPP framework can help organise the product landscape into archetypes which may serve competing or complementary roles across a health system. It provides strategic insights to optimise and guide CPAP product innovation while ensuring access, affordability and equity, and provides clarity on the critical attributes that are needed to tackle global health challenges especially in resource-limited settings. We assessed seven different devices across three geographies including Sub-Saharan Africa, South Asia and North America. The three main archetypes of CPAP products we have observed are described by features in table 1 . They include (1) low-cost, unbundled CPAP consisting of improvised or home-made bubble CPAP, or improvised bubble CPAP with enhanced components (eg, oxygen blender), (2) medium cost, integrated or

Table 1 Continuous positive airway pressure (CPAP) product archetype comparison

\begin{tabular}{|c|c|c|c|c|}
\hline \multirow[b]{2}{*}{ Features } & \multicolumn{2}{|c|}{ Low-cost, unbundled CPAP devices } & \multirow[b]{2}{*}{$\begin{array}{l}\text { Medium cost, bundled } \\
\text { CPAP }\end{array}$} & \multirow[b]{2}{*}{ High cost, bundled CPAP } \\
\hline & $\begin{array}{l}\text { Improvised/home-made } \\
\text { CPAP }\end{array}$ & $\begin{array}{l}\text { Improvised CPAP with } \\
\text { enhanced components }\end{array}$ & & \\
\hline Intended use & \multicolumn{4}{|c|}{ Initial treatment of newborns with respiratory distress } \\
\hline CPAP generator & Yes & Yes & Yes & Yes \\
\hline Air flow & $\begin{array}{l}\text { Requires external air flow } \\
\text { source }\end{array}$ & $\begin{array}{l}\text { Requires external air flow } \\
\text { source }\end{array}$ & Generates own air flow source & Requires external air flow source \\
\hline Oxygen source & $\begin{array}{l}\text { Requires external oxygen } \\
\text { and/or air source }\end{array}$ & $\begin{array}{l}\text { Requires external oxygen and/ } \\
\text { or air source }\end{array}$ & $\begin{array}{l}\text { Requires external oxygen } \\
\text { source, but has integrated air } \\
\text { source }\end{array}$ & $\begin{array}{l}\text { Requires external oxygen and/or } \\
\text { air source }\end{array}$ \\
\hline Oxygen blender & No & Yes, but not all & Yes, some may measure $\mathrm{FiO}_{2}$ & Yes, can measure $\mathrm{FiO}_{2}$ \\
\hline $\begin{array}{l}\text { Oxygen saturation } / \mathrm{FiO}_{2} \\
\text { measurement }\end{array}$ & $\begin{array}{l}\text { Requires pulse oximetry to } \\
\text { monitor saturation but no } \\
\mathrm{FiO}_{2} \text { regulation available }\end{array}$ & $\begin{array}{l}\text { Requires pulse oximetry to } \\
\text { monitor saturation and regulate } \\
\mathrm{FiO}_{2} \text { level }\end{array}$ & $\begin{array}{l}\text { May require pulse oximetry } \\
\text { to monitor saturation Some } \\
\text { devices allow } \mathrm{FiO}_{2} \text { to be } \\
\text { set directly without manual } \\
\text { calculations by user } \\
{ }^{\star} \text { One device is known to have } \\
\text { an integrated pulse oximeter }\end{array}$ & $\begin{array}{l}\text { Requires pulse oximetry to } \\
\text { monitor saturation, } \mathrm{FiO}_{2} \text { may } \\
\text { be set directly without manual } \\
\text { calculations by user } \\
{ }^{*} \text { One device is known to have an } \\
\text { integrated pulse oximeter }\end{array}$ \\
\hline Humidification & Relies on ambient humidity & $\begin{array}{l}\text { Relies on ambient humidity; } \\
\text { passive humidification }\end{array}$ & $\begin{array}{l}\text { May rely on ambient or have } \\
\text { passive or active heated } \\
\text { humidification }\end{array}$ & Heated humidification system \\
\hline Patient interface & Any nasal prongs & Any nasal prongs & $\begin{array}{l}\text { May use custom-made or } \\
\text { standard Hudson prongs }\end{array}$ & $\begin{array}{l}\text { May use custom-made or } \\
\text { standard Hudson prongs }\end{array}$ \\
\hline Tubing or circuit limbs & $\begin{array}{l}\text { Standard wide bore tubing, } \\
\text { inspiratory and expiratory } \\
\text { circuit }\end{array}$ & $\begin{array}{l}\text { Standard wide bore tubing, } \\
\text { inspiratory and expiratory } \\
\text { circuit }\end{array}$ & $\begin{array}{l}\text { May use custom-made or } \\
\text { Standard wide bore tubing, } \\
\text { inspiratory and expiratory } \\
\text { circuit } \\
{ }^{*} \text { One device is known to have } \\
\text { controlled heated inspiratory } \\
\text { circuit }\end{array}$ & $\begin{array}{l}\text { Insulated tubing and heated } \\
\text { breathing circuit }\end{array}$ \\
\hline Internal performance monitoring & $\begin{array}{l}\text { No internal performance } \\
\text { monitoring system: bubbling } \\
\text { of water in CPAP generator } \\
\text { chamber may be used as an } \\
\text { indicator }\end{array}$ & $\begin{array}{l}\text { No internal performance } \\
\text { monitoring system: bubbling } \\
\text { of water in CPAP generator } \\
\text { chamber may be used as an } \\
\text { indicator }\end{array}$ & $\begin{array}{l}\text { May include audio/visual alarm } \\
\text { notification system }\end{array}$ & $\begin{array}{l}\text { May include audio/visual alarm } \\
\text { notification system }\end{array}$ \\
\hline Power and battery & $\begin{array}{l}\text { Does not require electricity } \\
\text { except used with oxygen } \\
\text { concentrator }\end{array}$ & $\begin{array}{l}\text { Does not require electricity } \\
\text { except used with oxygen } \\
\text { concentrator }\end{array}$ & $\begin{array}{l}\text { Requires electricity, may include } \\
\text { backup battery, }\end{array}$ & Requires electricity \\
\hline Cost & $\begin{array}{l}\text { US\$1-4. } \\
\text { Does not include cost of } \\
\mathrm{O}_{2} \text { concentrator and other } \\
\text { consumables }\end{array}$ & $\begin{array}{l}\text { US\$100-200. } \\
\text { Does not include cost of } \mathrm{O}_{2} \\
\text { concentrator }\end{array}$ & $\begin{array}{l}\text { US\$1000-2000. } \\
\text { May or may not include cost of } \\
\text { consumables }\end{array}$ & US\$3000-6000 \\
\hline Regulatory approval & $\mathrm{N} / \mathrm{A}$ & CE mark possible & CE mark & CE mark \\
\hline Product Examples & & $\begin{array}{l}\text { (i)VAYU CPAP } \\
\text { (ii)PATH (KIWOKO) CPAP }\end{array}$ & $\begin{array}{l}\text { 1. Pumani (NEST) CPAP } \\
\text { 2. Equalise Health (D-REV) } \\
\text { nCPAP } \\
\text { 3. Polite CPAP }\end{array}$ & $\begin{array}{l}\text { 1. Fisher-Paykel bubble CPAP } \\
\text { 2. Dolphin MTTS }\end{array}$ \\
\hline
\end{tabular}

*This was not intended as an exhaustive list of examples of continuous positive airway pressure (CPAP) products. The authors do not endorse or critique any of the listed products but only highlight them for illustrative purposes. 
bundled CPAP devices, and (3) high-cost, integrated or bundled bubble CPAP devices.

These range of options might suggest that needs in this space are fulfilled; however, it is important to consider how each of the different categories of devices are suited for different segments within a health system. For example, depending on available resources, funding and support for newborn care in a given health system-a facility with consistent supply of wall oxygen and existing pulse oximetry monitoring tools may benefit from the use of improvised devices with oxygen blender; however, another facility may need an integrated device due to inconsistent availability of piped oxygen, lower patient to nursing ratio and vital signs monitoring. In another scenario, facilities may need to supplement occupied automated or commercial devices with the use of improvised devices when patient demand outweighs supply of devices. This may lead to decisions regarding which babies should receive treatment from a specific device and brings to light the ethical considerations that healthcare workers in this situation face daily. ${ }^{11}$

In addition to product specific technical requirements, understanding barriers and facilitators of widespread use and implementation of the device need to be carefully considered and addressed. For example, the presence of limited bedside personnel and understaffing of neonatal units may preclude the ability of health staff to rigorously monitor each infant on CPAP, as well as limit the amount of time available for trainings. ${ }^{4}$ This emphasises the need to design products that are integrated with automated capabilities and intuitive user interfaces, require minimal maintenance and are universally compatible with available consumables. Also, the availability of different types of devices may inadvertently limit utilisation and scale up due to the need to train staff on the set up, use and maintenance of varying devices in settings that are chronically understaffed. ${ }^{4}$

Furthermore, affordability is of utmost importance for market penetration and scalability in settings where the cost of devices remains out of reach. ${ }^{12}$ Total costs include more than the device itself, but also the costs of maintenance, wrap-around support, training, consumables and health worker time. Innovators need to factor in these additional costs when establishing target device cost per unit as it has dire implications on sustainability and long-term use.

To drive investment considerations, understanding of the drivers of healthcare worker behaviour, systemic issues that limit implementation such as availability of oxygen and constant supply of electricity, ${ }^{13}$ health ministry prioritisation of newborn health including flow of funds and procurement process for newborn care packages across the health system or facility level, tradeoff between needs such as purchasing essential medicines and supplies versus tools and devices, procurer choice of which CPAP device to purchase based on perceived value proposition of the device. All of these affect the design and ultimate uptake of CPAP and ancillary newborn care technologies and are necessary prerequisites when considering investments in a new product.

Other key factors to be considered include the commercialisation and distribution plan; current distribution channels for newborn care equipment are fragmented, with limited interests from commercial manufacturers and distributors to engage in the space due to smaller market size, low profit margins and high requirements for maintenance support. Leveraging existing distribution networks by partnering with local manufacturers and/or regional distributors for commercialisation is critical for scale. Having all these components in place is necessary to drive substantial investments in new product development. Investments in newborn care technology could help save millions of newborns around the world. Fortunately, the newborn technology space is rapidly improving, and the criteria set in the TPP on the product, such as cost, ease-of-use and target population or use case could play a pivotal role in effecting impact at scale. We propose the widespread use of a global health TPP when considering product innovation in newborn care technology, using CPAP as an example. We also emphasise the need to consider local systemic factors including affordability, health worker training, procurement policies, as well as scale and commercialisation strategy during product development. These factors are important for driving further investments towards maximal impact for newborn care in LMIC settings.

Twitter Bolanle Aishat Kasali @Aisha Kasali

Contributors BAK conceptualised and codesigned the study, drafted the initial manuscript and reviewed and revised the manuscript. All authors codesigned, coordinated and critically reviewed the manuscript for important intellectual content. All authors approved the final manuscript as submitted and agree to be accountable for all aspects of the work.

Funding This work was supported by Bill and Melinda Gates Foundation.

Competing interests $\mathrm{BAK}$ and $\mathrm{AG}$ have no competing interests to disclose. $\mathrm{MB}$ is involved in the development of the PATH (KIWOKO) CPAP device: one of the CPAP product examples listed in table 1.

Patient consent for publication Not required.

Provenance and peer review Not commissioned; externally peer reviewed.

Open access This is an open access article distributed in accordance with the Creative Commons Attribution 4.0 Unported (CC BY 4.0) license, which permits others to copy, redistribute, remix, transform and build upon this work for any purpose, provided the original work is properly cited, a link to the licence is given, and indication of whether changes were made. See: https:// creativecommons.org/licenses/by/4.0/.

ORCID iD

Bolanle Aishat Kasali http://orcid.org/0000-0003-4525-893X

\section{REFERENCES}

1 Lawn JE, Kinney MV, Belizan JM, et al. Born too soon: accelerating actions for prevention and care of 15 million 


\section{Discussion}

newborns born too soon. Reprod Health 2013;10 Suppl $1: S 6$.

2 Thukral A, Sankar MJ, Chandrasekaran A, et al. Efficacy and safety of CPAP in low- and middle-income countries. $J$ Perinatol 2016;36 Suppl 1:S21-8.

3 Dewez JE, van den Broek N. Continuous positive airway pressure (CPAP) to treat respiratory distress in newborns in low- and middle-income countries. Trop Doct 2017;47:1922.

4 Kinshella M-LW, Walker CR, Hiwa T, et al. Barriers and facilitators to implementing bubble CPAP to improve neonatal health in sub-Saharan Africa: a systematic review. Public Health Rev 2020;41:6.

5 WHO Library Cataloguing-in-Publication Data. Who recommendations on interventions to improve preterm birth outcomes. World Health Organization, 2015. ISBN: 978924 1508988.

6 WHO Library Cataloguing-in-Publication Data. Oxygen therapy for children: a manual for healthcare workers. World Health Organization, 2016. ISBN: 9789241549554.

7 World Health Organization. Standards for improving quality of care for small and sick newborns in health facilities. Geneva: World Health Organization, 2020.
8 Terry RF, Plasència A, Reeder JC. Analysis of the Health Product Profile Directory - a new tool to inform prioritysetting in global public health. Health Res Policy Syst 2019;17:97.

9 Brooks A, Nunes JK, Garnett A, et al. Aligning new interventions with developing country health systems: target product profiles, presentation, and clinical trial design. Glob Public Health 2012;7:931-45.

10 UNICEF. Nest 360. target product profiles for newborn care in low-resource settings (v1.2) consensus meeting report, 2020. Available: https://www.unicef.org/supply/sites/unicef. org.supply/files/2020-04/TPP-newborn-care-final-report-v1-2. pdf

11 Ntigurirwa P, Mellor K, Langer D, et al. A health partnership to reduce neonatal mortality in four hospitals in Rwanda. Global Health 2017;13:28.

12 Kawaza K, Machen HE, Brown J, et al. Efficacy of a low-cost bubble CPAP system in treatment of respiratory distress in a neonatal ward in Malawi. PLoS One 2014;9:e86327.

13 Aneji C, Hartman T, Olutunde O, et al. Implementing bubble continuous positive airway pressure in a lower middleincome country: a Nigerian experience. Pan Afr Med J 2020;37:10. 